\title{
Bioactivity of Peumus boldus Molina, Laurelia sempervirens (Ruiz \& Pav.) Tul. and Laureliopsis philippiana (Looser) Schodde (Monimiacea) essential oils against Sitophilus zeamais Motschulsky
}

\author{
Carmen Herrera-Rodríguez ${ }^{1}$, Carolina Ramírez-Mendoza ${ }^{1}$, Itzel Becerra-Morales ${ }^{1}$, \\ Gonzalo Silva-Aguayo ${ }^{2 *}$, Angélica Urbina-Parra², Inés Figueroa-Cares ${ }^{2}$, Luciano Martínez-Bolaños ${ }^{1}$, \\ J. Concepción Rodríguez-Maciel ${ }^{3}$, Angel Lagunes-Tejeda ${ }^{3}$, Edgar Pastene-Navarrete ${ }^{4}$, \\ and Luis Bustamante-Salazar ${ }^{4}$
}

\begin{abstract}
The maize weevil (Sitophilus zeamais Motschulsky) is one of most important pest of stored seeds worldwide, but its current control method is based on the use of synthetic insecticides, usually leading to undesirable problems such as insecticide residues on treated food, human intoxications, and insect resistance development. Therefore the search of friendly alternative methods is required. The aim of this study was to assess, under laboratory conditions, the insecticidal properties of Peumus boldus Molina, Laurelia sempervirens (Ruiz \& Pav.) Tul., and Laureliopsis philippiana (Looser) Schodde essential oils against $S$. zeamais. The phytochemical analysis of the three essential oils showed 1,8-cineole, safrole and methyleugenol as the common components; all of them documented with insecticidal activity from essential oils from other plant species The highest toxicity ( $100 \%$ mortality) of these three oils acting as a contact insecticide was observed at $24 \mathrm{~h}$ exposure at $4 \%$ concentration. The estimated $\mathrm{LC}_{50}$ values for P. boldus, L. sempervirens, and L. philippiana were $0.37,1.02$, and 0.28 $\mu \mathrm{L} \mathrm{g}^{-1}$, respectively. Peumus boldus exhibited the highest fumigant activity with $100 \%$ adult mortality at $30 \mu \mathrm{L}$ oil $\mathrm{L}^{-1}$ air. At $\geq 0.5 \%(\mathrm{v} / \mathrm{w})$ concentration, all essential oils showed repellent activity. These three essential oils showed a promissory insecticidal activity against the maize weevil.
\end{abstract}

Key words: Botanical insecticides, essential oils, maize weevil, stored grains.

\section{INTRODUCTION}

The maize weevil (Sitophilus zeamais Motschulsky; Coleoptera: Curculionidae) is known as a key pest of stored cereals because is able to feed on whole and undamaged grains. It may cause a complete grain loss in only 6-mo (Coitinho et al., 2011). Its control is usually performed with synthetic insecticides, leading to important problems such as the presence of undesirable residues on food and development of resistance to insecticides as phosphine (Pimentel et al., 2009), organophosphates and pyrethroids (Ribeiro et al., 2003). Recently, there has been a growing

${ }^{1}$ Universidad Autónoma Chapingo, Departamento de Parasitología Agrícola, km 38,5 Carretera México-Texcoco, Texcoco, México.

${ }^{2}$ Universidad de Concepción, Facultad de Agronomía, Av. Vicente Méndez 595, Chillán, Chile.

*Corresponding author (gosilva@udec.cl).

${ }^{3}$ Colegio de Postgraduados, Campus Montecillo, km 36,5 Carretera México-Texcoco, Texcoco, México.

${ }^{4}$ Universidad de Concepción, Facultad de Farmacia, Víctor Lamas 1290, Concepción, Chile.

Received: 27 November 2014.

Accepted: 14 April 2015.

doi:10.4067/S0718-58392015000400010 interest to evaluate the potential use of botanical insecticides, as powders, extracts or essential oils as a friendly alternative to synthetic insecticides.

Essential oils are common substances assessed against insect pest. These compounds may act as fumigants (Lee et al., 2004), contact insecticides, repellents and antifeedants (Isman, 2000). The toxicity of a large number of essential oils and their constituents has been evaluated against stored-product insects of Sitophilus genus as S. zeamais (Betancur et al., 2010), Sitophilus oryzae L. (Samboon and Pimsamarn, 2006), and Sitophilus granarius L. (Aslan et al., 2004).

In Chile research on insecticidal properties of essential oils is limited and has been focused on boldus (Peumus boldus Molina; Monimiaceae). For example, Urzúa et al. (2010) found insecticidal properties of $P$. boldus essential oil against Musca domestica L. and Bittner et al. (2008) and Betancur et al. (2010) indicated that this oil showed insecticidal activity against $S$. zeamais and Acanthoscelides obtectus. But the Monimiaceae family has other two native plants from Chile, Laurelia sempervirens (Ruiz \& Pav.) Tul. (Chilean laurel) and Laureliopsis philippiana (Looser) Schodde (tepa), and could have related or same chemical compounds and 
therefore similar insecticidal activity. Hence the objective of this research was to evaluate insecticidal properties of the essential oils of three Chilean native Monimiaceae trees; P. boldus, L. sempervirens, and L. philippiana against adults of $S$. zeamais under laboratory conditions.

\section{MATERIALS AND METHODS}

\section{Extraction and analysis of essential oils}

The essential oil of P. boldus and L. sempervirens were extracted from leaves field-collected from Los Lleuques zone (36 51 '18' S, 71³8'34" W; 286 m a.s.1.), Nuble province foothills, Chile. The foliage of L. philippiana was field-collected from the foothills of Maullín province ( $41^{\circ} 41^{\prime} \mathrm{S}, 73^{\circ} 25^{\prime} \mathrm{W}$; $28 \mathrm{~m}$ a.s.1.). All collections were carried out during January 2012, following Vogel et al. (1997) methodology. The taxonomic identification of collected foliage was verified according to reference vouchers CONC-CH5492 (P. boldus), CONC-CH237 (L. philippiana), and CONC-CH 809 (L. sempervirens) deposited in herbarium of Faculty of Agronomy of University of Concepción at Chillán. Once in the laboratory, only mature and whole leaves were washed with distilled water and dehydrated at $40{ }^{\circ} \mathrm{C}$ in a stove (Memmert Gmbh, UNB 500, Schwabach, Germany). The essential oils were obtained by steam distillation during $4 \mathrm{~h}$ using distilled water in a Clevenger type apparatus (Kouninki et al., 2007). Subsequently, the oil was treated with sodium sulfate to eliminate water traces and stored in amber-colored glass containers at $4.5^{\circ} \mathrm{C}$.

Chemical analysis of essential oils was assessed by gas cromatography (GC) coupled to mass spectrometry detection (GC-MS), using a high performance gas chromatography-mass spectrometry (HPGC-MS; HP 5890 Series II, Hewlett Packard, Palo Alto, California, USA). Separation was achieved using a $5 \%$ poly diphenyl 95\% dimethylsiloxane bonded phase column (i.d. 0.25 $\mathrm{mm}$, length $30 \mathrm{~m}$, film thickness $0.25 \mu \mathrm{m}$ ). Operation conditions were as follow: injector temperature, $250{ }^{\circ} \mathrm{C}$; carrier gas (Helium), flow rate $1 \mathrm{~mL} \mathrm{~min}^{-1}$ and split injection with a split ratio 1:20. Mass spectrometry conditions were as follows: ionization voltage, $70 \mathrm{eV}$; emission current $40 \mathrm{~mA}$; scan rate, $1 \mathrm{scan} \mathrm{s}^{-1}$; source temperature $285^{\circ} \mathrm{C}$. Mass range was 35-300 $\mathrm{Da}$. The oven temperature was 2 min isothermal at $60{ }^{\circ} \mathrm{C}$ and then increased to $210^{\circ} \mathrm{C}$, at the rate of $10{ }^{\circ} \mathrm{C} \mathrm{min}-1$, and to $260{ }^{\circ} \mathrm{C}$, at rate of $10^{\circ} \mathrm{C}$ $\min ^{-1}$. Samples $(1 \mu \mathrm{L})$ were dissolved with $\mathrm{CH}_{2} \mathrm{Cl}_{2}(1: 100$ $\mathrm{v} / \mathrm{v})$. The MS fragmentation pattern was checked with the standards available in our laboratory, and by matching the MS data with the library NIST NBS54K or literature (Adams, 2007). The relative amounts of each component were obtained from GC analysis using flame ionization detector in the same experimental conditions described for GC-MS analysis. In these conditions the linear retention indices (RI) were calculated using a mixture of n-alkanes $\left(\mathrm{C}_{8}-\mathrm{C}_{28}\right)$.

\section{Insects, grain, and bioassays}

The insects used in the bioassays were obtained from our laboratory colonies and reared in $1 \mathrm{~L}$ glass flasks containing maize (Zea mays L.) at $30 \pm 1{ }^{\circ} \mathrm{C}, 60 \pm 5 \% \mathrm{RH}$ and total darkness in a bioclimatic chamber (Memmert Gmbh, IPS 749, Schwabach, Germany). Maize for insect rearing and bioassays was obtained from the fruit and vegetable market of city of Chillán, Biobío Region, Chile. To avoid any previous infestation, the grain was washed and dried in a stove at $25^{\circ} \mathrm{C}$ for $12 \mathrm{~h}$ and then frozen at $-4.0 \pm 1{ }^{\circ} \mathrm{C}$ for $48 \mathrm{~h}$ prior to its use.

Mortality due to exposition to treated surface. The methodology of Kouninki et al. (2007) was followed and consisted of 6-mL test tubes treated with $1 \mathrm{~mL}$ of a solution of essential oil in acetone, at the required concentration. Then, the tubes were shaken for 1 min to allow the oil to cover the inner surface. The excess was eliminated by runoff and the acetone was allowed to evaporate at environmental temperature $\left(20 \pm 5^{\circ} \mathrm{C}\right)$ for $1 \mathrm{~h}$. Then 20 48-h old adult insects without sexing were placed in each tube. The evaluated doses of oils were $0.25,0.5,1$, 2 , and $4 \%(\mathrm{v} / \mathrm{v})$. The control consisted on using $1 \mathrm{~mL}$ of acetone without essential oil. Ten replicates were made at the same day per treatment and set up in a bioclimatic chamber at $30 \pm 1{ }^{\circ} \mathrm{C}, 60 \pm 5 \% \mathrm{RH}$ and total darkness. Insect mortality was assessed at 24 and $48 \mathrm{~h}$ exposure. The maximum level of mortality accepted for the control was $5 \%$ and it was corrected by means of the Abbott's formula (Abbott, 1925). An insect was considered dead when there was no movement after prodding it with a dissection needle for $5 \mathrm{~min}$.

Mortality due to exposure to treated grain. This bioassay was carried out with the methodology of Obeng-Oferi and Reichmuth (1997). Solutions of $1 \mathrm{~mL}$ of essential oil in acetone were applied to $400-\mathrm{mL}$ glass flasks with $200 \mathrm{~g}$ maize at the concentrations previously described. The flasks were covered and shaken for $15 \mathrm{~s}$ to cover the grains with oil, then uncovered and left for $2 \mathrm{~h}$ at room temperature $\left(20 \pm 5^{\circ} \mathrm{C}\right)$ to allow the acetone to evaporate. Immediately the flasks were infested with 20 48-h old adult insects without sexing. Each treatment was replicated ten times in $1 \mathrm{~d}$. The experimental units were stored in a bioclimatic chamber at $30 \pm 1{ }^{\circ} \mathrm{C}, 60 \pm 5 \% \mathrm{RH}$ and total darkness. Mortality assessment followed what was previously described.

Fumigant effect. This bioassay employed the methodology of Pires et al. (2006), which consisted of applying 0 (control), 15, 20, 25, 30, and $35 \mu \mathrm{L}$ of essential oil on a circular Whatman $\mathrm{nr} 10$ filter paper $(5.5 \mathrm{~cm}$ diameter, Whatman, Maidstone, Kent, UK), then the treated paper was attached to undersurface of screw caps of a $500-\mathrm{mL}$ plastic container (air volume equivalent to $0.5 \mathrm{~L}$ ) and 200 g maize infested with 20 48-h old adult insects without 
sexing were added. Ten replicates at one time were run for each concentration and control. Insect mortality was assessed at 24, 48, and $72 \mathrm{~h}$ exposure and it was corrected by means of the Abbott's formula (Abbott, 1925).

Repellent effect. The experimental unit was a choice arena consisting in a central plastic Petri dish $(5 \mathrm{~cm}$ diameter) connected to another four dishes through tubes $10 \mathrm{~cm}$ long and $0.5 \mathrm{~cm}$ in diameter forming an "X". Two opposite dishes containing $20 \mathrm{~g}$ maize grains were impregnated with the respective concentrations of essential oil, while other two dishes had maize grains treated only with acetone (Procopio et al., 2003). In the central Petri dish 20 individuals of $S$. zeamais of $48 \mathrm{~h}$ of age without sexing were released. The evaluated doses of oils were $0.25,0.5,1,2$, and $4 \%(\mathrm{v} / \mathrm{v})$ and each treatment had 10 replicates carried out simultaneously. Treatments were kept in a bioclimatic chamber for $24 \mathrm{~h}$ at $30 \pm 1{ }^{\circ} \mathrm{C}$, $60 \pm 5 \% \mathrm{RH}$ and total darkness and the number of insects that moved to each treatment was recorded. In each replicate the treatments were randomly rotated to avoid the interference of external factors. The repellent indexes were calculated according to Restello et al. (2009), in which the oil is classified as neutral if the index is between -0.10 to 0.10 , attracting if it is between 0.10 to 1.00 and repellent if it is between -1.00 to -0.10 .

Germination test of treated grain. The effect of essential oils on the germination of the maize grains was assessed using the methodology described by Pérez et al. (2007). Groups of 30 undamaged seeds were randomly selected. The groups of seeds were independently exposed to each of the following treatments; $0.25 \%, 0.5 \%, 1 \%, 2 \%$, and $4 \%(\mathrm{v} / \mathrm{v})$ and then placed separately on a glass Petri dish containing moistened filter paper at the bottom. These treatments were replicated ten times at the same day. The experimental units were kept at $25 \pm 1{ }^{\circ} \mathrm{C}, 60 \pm 5 \%$ $\mathrm{RH}$ and 12:12 h photoperiod during $7 \mathrm{~d}$ in a bioclimatic chamber. The percentage of germination in comparison to the untreated control was determined.

\section{Experimental design}

The experimental design was a completely random with a factorial arrangement. The percentage was transformed to the $\sqrt{ } \mathrm{x} / 100$ arcsine function prior to carry out ANOVA ( $\alpha=0.05$ ) test with the Statistical Analysis System (SAS) software (SAS Institute, Cary, North Carolina, USA) to determine if at least one treatment was different from the rest. If so, a Tukey means comparison test was used ( $\mathrm{p} \leq$ $0.05)$. To obtain the lethal concentration $50 \%\left(\mathrm{LC}_{50}\right)$ and $95 \%\left(\mathrm{LC}_{90}\right)$ data were subjected to Probit analysis using PROC PROBIT procedure of SAS software to determine $\mathrm{LC}_{50 / 95}$ values. Probit analysis responses were considered different when their respective fiducially limits did not overlap at a given mortality level (50\% or $95 \%)$ (Robertson and Preisler, 1992).

\section{RESULTS AND DISCUSSION}

\section{Phytochemical analysis}

The analysis of $P$. boldus essential oil showed ascaridole $(24.37 \%)$ and 1,8 -cineole $(14.85 \%)$ as the main components (Table 1). Ascaridole, as one of the most abundant components agrees with the results of Bittner et al. (2008) and Niemeyer and Teillier (2007) who documented concentrations as high as $38.9 \%$ and $60.3 \%$, respectively. However, Urzúa et al. (2010) considered that 1,8-cineole was the main component $(36.62 \%)$ of $P$. boldus. Perhaps, in our study this proportion was lower due to the effect of field collection date because all authors collected in the Biobío Region but Urzúa et al. (2010) collected leaves in November, Bittner et al (2008) in June, and we did it in March. In the case of L.philippiana, safrole $(39.56 \%)$, linalool $(34.45 \%)$, and 1,8 -cineole $(8.28 \%)$ were the compounds found at higher concentrations (Table 2). Our results are similar to those documented by Niemeyer and Teillier (2007) who detected an analogous level of 1,8-cineole concentration; although

Table 1. The main constituents of essential oil from Peumus boldus determined by gas chromatography and gas chromatography-mass spectrometry detection.

\begin{tabular}{|c|c|c|c|}
\hline Compound & $\mathrm{RI}^{1}$ & $\%$ & Identification $^{2}$ \\
\hline$\alpha$-Thujene & 930 & 0.32 & RI, MS, S \\
\hline 1R- $\alpha$-Pinene & 939 & 2.28 & RI, MS, S \\
\hline Camphene & 952 & 0.10 & RI, MS \\
\hline$\beta$-Pinene & 979 & 0.42 & RI, MS, S \\
\hline$\beta$-Myrcene & 993 & 2.00 & RI, MS, S \\
\hline d-2-Carene & 1001 & 0.25 & RI, MS \\
\hline$\alpha$-Phellandrene & 1002 & 0.21 & RI, MS, S \\
\hline$\alpha$-Terpinene & 1013 & 3.94 & RI, MS, S \\
\hline Limonene & 1030 & 2.95 & RI, MS, S \\
\hline$\beta$-Phellandrene & 1031 & 4.42 & RI, MS, S \\
\hline trans- $\beta$-Ocymene & 1036 & 12.87 & RI, MS \\
\hline 1,8-Cineol & 1039 & 14.85 & RI, MS, S \\
\hline cis- $\beta$-Ocymene & 1042 & 0.45 & RI, MS \\
\hline$\gamma$-Terpinene & 1057 & 1.86 & RI, MS, S \\
\hline Terpinolene & 1086 & 0.15 & RI, MS, S \\
\hline p-Cymenene & 1090 & 0.21 & RI, MS \\
\hline 2-Nonanone & 1093 & 0.15 & RI, MS, S \\
\hline trans-Sabinene hydrate & 1097 & 4.07 & RI, MS \\
\hline Dehydro-sabina ketone & 1121 & 0.36 & RI, MS \\
\hline trans-Pinocarveol & 1140 & 0.57 & RI, MS \\
\hline Camphor & 1146 & 0.10 & RI, MS, S \\
\hline Terpinen-4-ol & 1179 & 3.37 & RI, MS, S \\
\hline Cryptone & 1186 & 0.68 & RI, MS \\
\hline$\alpha$-Terpineol & 1187 & 2.14 & RI, MS, S \\
\hline Myrtenal & 1193 & 0.31 & RI, MS, S \\
\hline Myrtenol & 1194 & 0.20 & RI, MS, S \\
\hline Bornyl acetate & 1265 & 0.64 & RI, MS, S \\
\hline Ascaridole & 1273 & 24.37 & RI, MS, S \\
\hline$\beta$-Elemene & 1280 & 0.73 & RI, MS \\
\hline Safrole & 1285 & 1.45 & RI, MS \\
\hline 2-Undecanone & 1295 & 0.27 & RI, MS \\
\hline Methyleugenol & 1372 & 0.46 & RI, MS, S \\
\hline$\alpha$-Caryophyllene & 1419 & 0.78 & RI, MS, S \\
\hline Aromadendrene & 1440 & 0.43 & RI, MS, S \\
\hline$\alpha$-Caryophyllene & 1454 & 0.73 & RI, MS, S \\
\hline Germacrene D & 1480 & 0.45 & RI, MS \\
\hline$\partial$-Cadinene & 1524 & 0.24 & $\mathrm{RI}, \mathrm{MS}, \mathrm{S}$ \\
\hline 8,9-Dehydro-neoisolongifolene & 1558 & 0.80 & RI, MS \\
\hline
\end{tabular}

${ }^{1}$ Kovats retention index was determined on a DB-5 column in reference to n-alkanes.

${ }^{2}$ Compounds, identified by comparison with mass spectra (MS) from database, retention indices $(\mathrm{RI})$, and pure standards $(\mathrm{S})$. 
Table 2. The main constituents of essential oil from Laurelia sempervirens determined by gas chromatography and gas chromatography-mass spectrometry detection.

\begin{tabular}{lccc}
\hline Compound & RI $^{1}$ & $\%$ & Identification $^{2}$ \\
\hline$\alpha$-Thujene & 930 & 0.23 & RI, MS \\
1R- $\alpha$-Pinene & 939 & 0.76 & RI, MS \\
Sabinene & 963 & 0.22 & RI, MS, S \\
$\beta$-Pinene & 972 & 0.16 & RI, MS, S \\
$\alpha$-Phellandrene & 1002 & 0.56 & RI, MS, S \\
Limonene & 1030 & 1.33 & RI, MS, S \\
$\alpha$-Phellandrene & 1031 & 1.28 & RI, MS, S \\
p-Cymene & 1033 & 0.25 & RI, MS \\
1,8-Cineol & 1039 & 1.47 & RI, MS, S \\
cis- $\beta$-Ocymene & 1042 & 0.30 & RI, MS \\
$\gamma$-Terpinene & 1057 & 0.03 & RI, MS, S \\
Terpinolene & 1086 & 0.10 & RI, MS, S \\
p-Linalool & 1089 & 9.91 & RI, MS, S \\
4-Terpineol & 1179 & 0.10 & RI, MS, S \\
$\alpha$-Terpineol & 1187 & 0.87 & RI, MS, S \\
2-Pinen-10-ol & 1196 & 0.03 & RI, MS \\
Safrole & 1285 & 64.70 & RI, MS, S \\
$\alpha$-Terpinyl acetate & 1343 & 0.06 & RI, MS \\
Eugenol & 1356 & 0.51 & RI, MS, S \\
Methyleugenol & 1372 & 14.64 & RI, MS, S \\
Germacrene D & 1480 & 0.95 & RI. MS, S \\
$\beta$-Elemol & 1543 & 0.02 & RI, MS \\
\hline
\end{tabular}

${ }^{1}$ Kovats retention index was determined on a DB-5 column in reference to n-alkanes.

${ }^{2}$ Compounds identified by comparison with mass spectra (MS) from database, retention indices $(\mathrm{RI})$, and pure standards $(\mathrm{S})$.

linalool $(43.4 \%)$ was found in higher amount than safrole $(21.4 \%)$. However, Bittner et al. (2008) indicated that safrole was detected at $2.33 \%$, and the compounds at higher concentrations were 3 -carene $(53.8 \%), 1,8$-cineole $(14.76 \%)$ and 1,2-dimethoxy4-(2-propenyl)-phenol (10.58\%). In this case the difference with Bittner et al. (2008) is maybe also due to field collection date more a geographical zone effect because these authors collected in Concepción ( $36^{\circ} 50^{\prime} \mathrm{S}, 7^{\circ} 03^{\prime} \mathrm{W}$; $12 \mathrm{~m}$ a.s.1.), Biobío Region, and Niemeyer and Teillier (2007) and we did it in Puyehue (40³9.9' S, $72^{\circ} 10.3^{\prime} \mathrm{W} ; 364 \mathrm{~m}$ a.s.1.) and Maullín $\left(41^{\circ} 41^{\prime} \mathrm{S}, 73^{\circ} 25^{\prime} \mathrm{W}\right.$; $28 \mathrm{~m}$ a.s.1.) respectively, both located in Los Lagos Region.

The main components of the L. sempervirens essential oil were safrole $(64.7 \%)$, methyleugenol $(14.6 \%)$, and 1,8-cineol (1.4\%) (Table 3). These results agree with those of Bittner et al. (2008) and Montenegro et al. (2012) who estimated $65 \%$ and $69 \%$ concentration of safrole in essential oil from leaves and bark, respectively. However, the concentration of 1,8-cineol is different from the $14.7 \%$ obtained by Bittner et al. (2008) probably due to field collection date. About insecticidal activity of identified compounds Huang et al. (2002) indicated that safrole and methyleugenol have insecticidal properties against $S$. zeamais and Tribolium castaneum and according to ObengOferi and Reichmuth (1997) this compound also affects S. granarius, S. zemais, T. castaneum, and Prostephanus truncatus (Horn) (Coleoptera: Bostrichidae). Safrole has been considered as an attractive kairomone of Bactrocera dorsalis (Hendel) (Vargas et al., 2000; Shelly and Edu, 2008) and B. cucurbitae (Coquillet) (Vargas et al., 2000) and antifeedant against Pieris rapae (Yano and
Table 3. The main constituents of essential oil from Laureliopsis philippiana determined by gas chromatography and gas chromatography-mass spectrometry detection.

\begin{tabular}{|c|c|c|c|}
\hline Compound & $\mathrm{RI}^{1}$ & $\%$ & Identification $^{2}$ \\
\hline$\alpha$-Thujene & & 0.04 & RI, MS \\
\hline$(1 R)$ - $\alpha$-Pinene & 939 & 0.49 & $\mathrm{RI}, \mathrm{MS}, \mathrm{S}$ \\
\hline Sabinene & 963 & 0.81 & $\mathrm{RI}, \mathrm{MS}, \mathrm{S}$ \\
\hline$\beta$-Pinene & 972 & 0.59 & RI, MS, S \\
\hline$\beta$-Myrcene & 993 & 0.25 & RI, MS, S \\
\hline$\alpha$-Phellandrene & 1002 & 1.55 & $\mathrm{RI}, \mathrm{MS}, \mathrm{S}$ \\
\hline Limonene & 1030 & 0.77 & RI, MS, S \\
\hline Unknown & 1032 & 0.11 & $\mathrm{RI}, \mathrm{MS}, \mathrm{S}$ \\
\hline E-Ocymene & 1037 & 0.05 & RI, MS, S \\
\hline 1,8-Cineol & 1039 & 8.28 & RI, MS, S \\
\hline$\beta$-Ocymene & 1047 & 0.12 & RI, MS, S \\
\hline$\gamma$-Terpinene & 1057 & 0.14 & $\mathrm{RI}, \mathrm{MS}, \mathrm{S}$ \\
\hline Terpinolene & 1086 & 0.28 & RI, MS, S \\
\hline 2-Nonanone & 1093 & 0.05 & RI, MS, S \\
\hline Linalool & 1100 & 34.45 & $\mathrm{RI}, \mathrm{MS}, \mathrm{S}$ \\
\hline 4-Terpineol & 1179 & 0.45 & RI, MS, S \\
\hline p-Cymen-8-ol & 1185 & 0.07 & RI, MS, S \\
\hline$\alpha$-Terpineol & 1187 & 3.32 & $\mathrm{RI}, \mathrm{MS}, \mathrm{S}$ \\
\hline Safrole & 1285 & 39.56 & RI, MS, S \\
\hline Isoledene & 1336 & 0.21 & RI, MS, S \\
\hline Eugenol & 1356 & 1.41 & $\mathrm{RI}, \mathrm{MS}, \mathrm{S}$ \\
\hline Methyleugenol & 1372 & 3.06 & RI, MS, S \\
\hline Germacrene D & 1480 & 0.84 & RI, MS, S \\
\hline$\partial$-Cadinene & 1527 & 0.03 & $\mathrm{RI}, \mathrm{MS}, \mathrm{S}$ \\
\hline Spatulenol & 1586 & 0.21 & RI, MS, S \\
\hline
\end{tabular}

${ }^{1}$ Kovats retention index was determined on a DB-5 column in reference to n-alkanes.

${ }^{2}$ Compounds identified by comparison with mass spectra (MS) from database, retention indices $(\mathrm{RI})$, and pure standards $(\mathrm{S})$

Kamimura, 1993). In the case of 1,8-cineol, Lee et al. (2004) mentioned this component as a potential fumigant against stored grain pests.

\section{Mortality by contact with a treated surface}

Peumus boldus and L. sempervirens caused 100\% mortality at concentrations of $2 \%$ and $4 \%$ of essential oil, but in both species these treatments did not show differences $(\mathrm{p}=0.99)$ with the $1.0 \%$ that exhibited 88.8 (P. boldus) and $76.7 \%$ (L. sempervirens) of dead insects, respectively. In case of $P$. boldus our results agree with Betancur et al. (2010) who observed 100\% of dead insect at $4 \%$ concentration. Laureliopsis philippiana reached $100 \%$ mortality at $4 \%$ without significant differences with the $2 \%$ concentration (Table 4). At $48 \mathrm{~h}, 1 \%$ concentration of essential oil of P. boldus achieved $91.9 \%$ mortality, without significant differences with the mortality (100\%) obtained with $2 \%$ and $4 \%$ concentrations. At the same evaluation $2.0 \%$ of essential oil of L. sempervirens after $24 \mathrm{~h}$ exposure lead $83 \%$ mortality, while at $48 \mathrm{~h}$ this value significantly ( $p=0.001$ ) increased to $92.9 \%$. Laureliopsis philippiana did not show differences at $48 \mathrm{~h}$.

\section{Mortality by contact with treated grain}

At $24 \mathrm{~h}$, treatments consisting of $2 \%$ and $4 \%$ of P. boldus essential oil reached $100 \%$ mortality and this value was significantly $(p=0.001)$ higher than those observed with the rest of the treatments (Table 5). The essential oil of L. sempervirens at $4 \%$, showed $82.7 \%$ mortality, differing from all other essential oil concentrations. Laureliopsis 
Table 4. Mortality at 24 at 48 h of adult Sitophilus zeamais exposed to treated glass surface with the essential oil of Peumus boldus, Laurelia sempervirens, and Laureliopsis philippiana (Monimiacea) at different concentrations.

\begin{tabular}{|c|c|c|c|c|c|c|}
\hline \multirow[b]{2}{*}{ Concentration } & \multicolumn{3}{|c|}{$24 \mathrm{~h}$} & \multicolumn{3}{|c|}{$48 \mathrm{~h}$} \\
\hline & P. boldus & L. sempervirens & L.philippiana & P. boldus & L. sempervirens & L. philippiana \\
\hline$\%$ & & & ( & 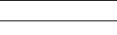 & 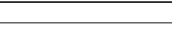 & $\bar{z}$ \\
\hline 0.25 & $0.0 \mathrm{Ac}$ & $3.0 \mathrm{Ab}$ & 7.0Ac & $1.3 \mathrm{ABc}$ & $2.0 \mathrm{Bc}$ & $18.9 \mathrm{Ac}$ \\
\hline 0.50 & $33.3 \mathrm{Ab}$ & $13.0 \mathrm{Ab}$ & $43.4 \mathrm{Ab}$ & $39.2 \mathrm{Ab}$ & $24.2 \mathrm{Ac}$ & $44.5 \mathrm{Abc}$ \\
\hline 1.00 & 88.9Aa & $31.1 \mathrm{Bb}$ & 76.7Aa & 91.9Aa & $40.0 \mathrm{Bb}$ & 79.7Aab \\
\hline 2.00 & $100.0 \mathrm{Aa}$ & 83.0Aa & $100.0 \mathrm{Aa}$ & $100.0 \mathrm{Aa}$ & $92.9 \mathrm{Aa}$ & $100.0 \mathrm{Aa}$ \\
\hline 4.00 & $100.0 \mathrm{Aa}$ & $100.0 \mathrm{Aa}$ & $100.0 \mathrm{Aa}$ & $100.0 \mathrm{Aa}$ & $100.0 \mathrm{Aa}$ & $100.0 \mathrm{Aa}$ \\
\hline
\end{tabular}

Within the same column, the values with the same lower-case letter are not significantly different according to Tukey test ( $\mathrm{p} \leq 0.05$ ).

Within the same row, the values with the same uppercase letter are not significantly different according to Tukey test (p $\leq 0.05)$.

Table 5. Mortality at 24 and 48 h of adults of Sitophilus zeamais exposed to treated grain with essential oil of Peumus boldus, Laurelia sempervirens, and Laureliopsis philippiana (Monimiacea) at different concentrations.

\begin{tabular}{|c|c|c|c|c|c|c|}
\hline \multirow[b]{2}{*}{ Concentration } & \multicolumn{3}{|c|}{$24 \mathrm{~h}$} & \multicolumn{3}{|c|}{$48 \mathrm{~h}$} \\
\hline & P. boldus & L. sempervirens & L. philippiana & P. boldus & L. sempervirens & L. philippiana \\
\hline$\%$ & & & $x^{2}$ & & & - \\
\hline 0.25 & $0.0 \mathrm{Ab}$ & $0.2 \mathrm{Acd}$ & $0.0 \mathrm{Ad}$ & $0.0 \mathrm{Ab}$ & 5.1Acd & $2.5 \mathrm{Ac}$ \\
\hline 0.50 & $27.5 \mathrm{Ab}$ & 5.1Ad & $30.0 \mathrm{Ac}$ & $22.2 \mathrm{Ab}$ & 7.5Ad & $46.2 \mathrm{Ab}$ \\
\hline 1.00 & $31.6 \mathrm{ABb}$ & $6.3 \mathrm{Bc}$ & $68.7 \mathrm{Ab}$ & $28.8 \mathrm{Bb}$ & $11.5 \mathrm{Bc}$ & $92.5 \mathrm{Aa}$ \\
\hline 2.00 & $95.0 \mathrm{Aa}$ & $25.3 \mathrm{Bb}$ & $100.0 \mathrm{Aa}$ & $100.0 \mathrm{Aa}$ & $32.5 \mathrm{Bb}$ & $100.0 \mathrm{Aa}$ \\
\hline 4.00 & $100.0 \mathrm{Aa}$ & $82.3 \mathrm{Ba}$ & $100.0 \mathrm{Aa}$ & $100.0 \mathrm{Aa}$ & $91.2 \mathrm{Aa}$ & $100.0 \mathrm{Aa}$ \\
\hline
\end{tabular}

Within the same column, the values with the same lower-case letter are not significantly different according to Tukey test ( $\mathrm{p} \leq 0.05)$.

Within the same row, the values with the same uppercase letter are not significantly different according to Tukey test ( $\mathrm{p} \leq 0.05$ ).

philippiana at $2 \%$ and $4 \%$ concentrations produced $95 \%$ and $100 \%$ mortality, respectively. After $48 \mathrm{~h}$ exposure, without statistical difference $(p=0.34)$, the essential oil of L. sempervirens caused $91.2 \%$ mortality at $4 \%$ concentration and L. philippiana at $2 \%$ reached $100 \%$. The results with $P$. boldus are similar to those obtained by Betancur et al. (2010) who estimated $98 \%$ mortality at $4 \%$ concentration of essential oil. The $\mathrm{LC}_{50}$ values at $48 \mathrm{~h}$ were $0.37,1.02$, and $0.28 \mu \mathrm{L} \mathrm{g}^{-1}$ ( $\mu \mathrm{L}$ essential oil $\mathrm{g}^{-1}$ grain) for $P$. boldus, L. sempervirens, and L. philippiana, respectively. Since their fiducial limits overlapped (Robertson and Preisler, 1992), there were no differences among them (Table 6). The $\mathrm{LC}_{50}$ values obtained with essential oil of $P$. boldus and L. philippiana show a higher toxicity than other essential oils assessed against $S$. zeamais, such as Piper crassinervium Kunth (Piperaceae) $\left(0.71 \mu \mathrm{L} \mathrm{g}^{-1}\right)$ (Salgado et al., 2012); Eugenia uniflora L. (Myrtaceae) (11.6 $\mu \mathrm{L} 40 \mathrm{~g}^{-1}$ grain); Cinnamomum zeylanicum Blume

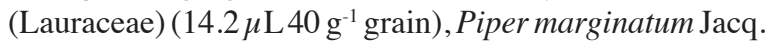

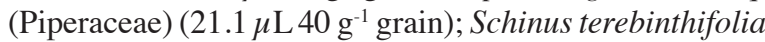
Raddi (Anacardiaceae) $\left(57.7 \mu \mathrm{L} 40 \mathrm{~g}^{-1}\right)$; and Melaleuca leucadendron L. (Myrtaceae) (75.8 $\mu \mathrm{L} 40 \mathrm{~g}^{-1}$ grain) (Coitinho et al., 2011). The essential oil of P. boldus and L. philippiana are also more toxic to $S$. zeamais than cymol isolated from Eucalyptus saligna Sm. (Myrtaceae) and Cupressus sempervirens L. (Cupressaceae) $(38.05 \mu \mathrm{L}$ $40 \mathrm{~g}^{-1}$ grain) (Tapondjou et al., 2005).

The toxicity by direct applications of L. sempervirens and L. philippiana may be due to the safrole compound activity, which is the most abundant component in its essential oils (Tables 2 and 3 ) because according to Huang et al. (2002), safrole and isosafrole have contact and fumigant toxicity against adults of $S$. zeamais and $T$. castaneum.

\section{Fumigant effect}

The highest toxicity was observed in P. boldus essential oil where all evaluated concentrations exceeded $90 \%$ mortality at $24 \mathrm{~h}$. The concentration of $70 \mu \mathrm{L} \mathrm{L}^{-1}$ air of L. sempervirens essential oil showed $58.62 \%$ dead insects without differences $(p=0.74)$ with 50 and 60 $\mu \mathrm{L} \mathrm{L} \mathrm{L}^{-1}$ air that reached $31 \%$ and $41.3 \%$ mortality (Table 7). Laureliopsis philippiana registered a maximum mortality of $56.6 \%$ at $70 \mu \mathrm{L} \mathrm{L}^{-1}$ air being significantly ( $p$ $=0.001$ ) higher in comparison with the rest of treatments. After $48 \mathrm{~h}$ exposure, $35 \mu \mathrm{L} \mathrm{L}^{-1}$ air of L. sempervirens and L. philippiana reached $86 \%$ and $95 \%$ mortality, but did not show differences with 40 and $60 \mu \mathrm{L} \mathrm{L}^{-1}$ air. At $72 \mathrm{~h}$, L. sempervirens and L. philippiana at $70 \mu \mathrm{L} \mathrm{L}^{-1}$ showed $100 \%$ and $98.3 \%$ mortality. Perhaps the toxicity

Table 6. Lethal concentration at $50 \%\left(C L_{50}\right)$ and $95 \%$ mortality $\left(C^{2} L_{95}\right)$ of essential oils of Peumus boldus, Laurelia sempervirens, and Laureliopsis philippiana (Monimiacea) against Sitophilus zeamais by contact effect.

\begin{tabular}{|c|c|c|c|c|c|c|c|}
\hline Essential oil & $\mathrm{n}$ & $\mathrm{CL}_{50}$ & $\mathrm{CL}_{95}$ & Slope \pm SE & $\mathrm{X}^{2}$ & Df & $p$-Value \\
\hline$\%$ & \multicolumn{7}{|c|}{$\mu \mathrm{L} \mathrm{g}^{-1}$} \\
\hline P. boldus & 200 & $0.37(0.15-1.06)$ & $1.05(0.55-188)$ & $3.7 \pm 0.95$ & 0.0001 & 3 & 0.0001 \\
\hline L. sempervirens & 200 & $1.02(0.53-8.9)$ & $3.6(1.6-21659)$ & $3.0 \pm 0.79$ & 0.0002 & 3 & 0.0001 \\
\hline L. philippiana & 200 & $0.28(0.18-0.44)$ & $0.64(0.41-3.32)$ & $4.6 \pm 0.69$ & 0.0001 & 3 & 0.0386 \\
\hline
\end{tabular}

$\mathrm{n}$ : Total number of insect tested in 10 replicates per treatment; Df: degrees of freedom; $\mathrm{X}^{2}$ : chi-square.

Values in parenthesis correspond lower and upper of confidence limits at $95 \%$ of probability. 
Table 7. Mortality at 24, 48, and $72 \mathrm{~h}$ of Sitophilus zeamais adults by fumigant effect of the essential oils of Peumus boldus, Laurelia sempervirens, and Laureliopsis philippiana (Monimiacea) at the different concentrations.

\begin{tabular}{|c|c|c|c|c|c|c|c|c|c|}
\hline \multirow[b]{2}{*}{ Concentration } & \multicolumn{3}{|c|}{$24 \mathrm{~h}$} & \multicolumn{3}{|c|}{$48 \mathrm{~h}$} & \multicolumn{3}{|c|}{$72 \mathrm{~h}$} \\
\hline & P. boldus & L. sempervirens & L.philippiana & P. boldus & L. sempervirens & L.philippiana & P. boldus & L. sempervirens & L.philippiana \\
\hline$\mu \mathrm{L}$ oil $\mathrm{L}^{-1}$ air & & & & & $\%$ & & & & - \\
\hline 30 & $95 \mathrm{Aa}$ & $0.0 \mathrm{Bb}$ & $3.3 \mathrm{Cb}$ & $95 \mathrm{Aa}$ & $0.0 \mathrm{Bb}$ & $36.66 \mathrm{Bb}$ & 98.30Aa & $20.68 \mathrm{Bc}$ & $57.6 \mathrm{Bb}$ \\
\hline 40 & $100 \mathrm{Aa}$ & $27.6 \mathrm{Bb}$ & $11.6 \mathrm{Bb}$ & $100 \mathrm{Aa}$ & $37.9 \mathrm{Ba}$ & 61.7Bab & $100.00 \mathrm{Aa}$ & $68.96 \mathrm{Bb}$ & 61.7ABab \\
\hline 50 & $100 \mathrm{Aa}$ & $31.0 \mathrm{Ba}$ & $16.7 \mathrm{Cb}$ & $100 \mathrm{Aa}$ & $44.8 \mathrm{Ba}$ & 66.7Bab & $100.00 \mathrm{Aa}$ & $72.41 \mathrm{Bab}$ & $86.4 \mathrm{Bab}$ \\
\hline 60 & $100 \mathrm{Aa}$ & $41.4 \mathrm{Ba}$ & $25.0 \mathrm{Cb}$ & $100 \mathrm{Aa}$ & $69.0 \mathrm{Ba}$ & 78.3Bab & $100.00 \mathrm{Aa}$ & $93.10 \mathrm{Ba}$ & $96.6 \mathrm{ABab}$ \\
\hline 70 & $100 \mathrm{Aa}$ & $58.6 \mathrm{Ba}$ & $56.7 \mathrm{Ba}$ & $100 \mathrm{Aa}$ & $86.2 \mathrm{Ba}$ & $95.0 \mathrm{ABa}$ & $100.00 \mathrm{Aa}$ & $100.00 \mathrm{Aa}$ & $98.3 \mathrm{Aa}$ \\
\hline
\end{tabular}

Within the same column, the values with the same lower-case letter are not significantly different according to Tukey test ( $\mathrm{p} \leq 0.05$ ).

"Within the same row, the values with the same uppercase letter are not significantly different according to Tukey test ( $\mathrm{p} \leq 0.05$ ).

observed is mainly due to the action of 1,8-cineole present in P. boldus (14.87\%), L. sempervirens $(1.47 \%)$, and L. philippiana ( $8.28 \%$ ) because according to Lee et al. (2004), 1,8-cineole assessed alone, showed a mortality higher than $90 \%$ in adults of S. zemais, S. oryzae, T. castaneum, and Rhyzopertha dominica.

\section{Repellent effect}

In L. philippiana, all concentrations were repellent to $S$. zeamais (Table 8). In P. boldus and L. sempervirens, only the treatments of $0.125 \%$ of essential oil did not show repellent effect while the others did. Betancur et al. (2010) obtained similar results with the essential oil of $P$. boldus, concluding that repellency is a useful and complementary effect to contact insecticidal activity, since it decreases the possibility of new infestations. The absence of repellent effect in lower essential oil concentrations agree with Nerio et al. (2009) and Conti et al. (2010) who argue that as the monoterpenes concentration increases, the repellent effect increases too. Thus if the monoterpenes concentration is lower, usually the most abundant components in essential oils, lower will be the repellency.

\section{Germination test of treated grain}

The $P$. boldus essential oil at $4 \%$ concentration was the only treatment that negatively affected grain germination $(<50 \%)$ (Table 9). Our results with L. philippiana and the rest of P. boldus treatments $(<4.0 \%)$ agree with those of Betancur et al. (2010) and Ortiz et al. (2012) who did not obtain differences in the germination level between non treated and treated seed with powder of L. philippiana and $P$. boldus. The decrease in the percent reduction of seed germination was documented by Pérez et al. (2007)

Table 8. Repellence index of the essential oils of Peumus boldus, Laurelia sempervirens, and Laureliopsis philippiana (Monimiacea) on Sitophilus zeamais adults.

\begin{tabular}{cccc}
\hline $\begin{array}{c}\text { Concentration } \\
(\%)\end{array}$ & P. boldus & L. sempervirens & L. philippiana \\
\hline 0.125 & $0.1(\mathrm{~A})$ & $0.2(\mathrm{~A})$ & $-0.4(\mathrm{R})$ \\
0.25 & $-0.2(\mathrm{R})$ & $-0.1(\mathrm{R})$ & $-0.4(\mathrm{R})$ \\
0.50 & $-0.03(\mathrm{R})$ & $-0.2(\mathrm{R})$ & $-0.4(\mathrm{R})$ \\
1.00 & $-0.2(\mathrm{R})$ & $-0.2(\mathrm{R})$ & $-0.2(\mathrm{R})$ \\
2.00 & $-0.4(\mathrm{R})$ & $-0.5(\mathrm{R})$ & $-0.6(\mathrm{R})$ \\
4.00 & $-0.5(\mathrm{R})$ & $-0.1(\mathrm{R})$ & $-0.2(\mathrm{R})$ \\
\hline
\end{tabular}

A: Attractive, N: neutral, R: repellent. with $P$. boldus at $\geq 4.0 \%$ concentration, perhaps due to the presence of certain compounds concentrations influenced by the time that the foliage was field-collected. This is

Table 9. Germination of maize seeds exposed to different concentrations of essential oil of Peumus boldus, Laurelia sempervirens, and Laureliopsis philippiana (Monimiacea).

\begin{tabular}{clcl}
\hline Concentration & P. boldus & L. sempervirens & L. philippiana \\
\hline \cline { 2 - 4 }$(\%)$ & $65.8 \mathrm{Aa}$ & $70.0 \mathrm{Aa}$ & \\
Control & $72.5 \mathrm{Aa}$ & $65.0 \mathrm{ABa}$ & $72.5 \mathrm{Aa}$ \\
0.25 & $59.2 \mathrm{Aa}$ & $71.6 \mathrm{Aa}$ & $54.1 \mathrm{Bab}$ \\
0.50 & $76.7 \mathrm{ABa}$ & $83.3 \mathrm{Aa}$ & $48.3 \mathrm{Ab}$ \\
1.00 & $65.0 \mathrm{ABa}$ & $81.6 \mathrm{Aa}$ & $61.6 \mathrm{Bab}$ \\
2.00 & $22.5 \mathrm{Ab}$ & $75.8 \mathrm{Aa}$ & $51.6 \mathrm{Bab}$ \\
4.00 & & & $55.8 \mathrm{Aab}$ \\
\hline
\end{tabular}

Values with the same lower-case letter are not different according to Tukey test ( $\mathrm{p} \leq 0.05$ ), within the same column.

Values with the same uppercase letter are not different according to Tukey test ( $\mathrm{p} \leq 0.05)$, within the same row.

one of reasons why botanical insecticides do not have a widespread use in agriculture.

\section{CONCLUSIONS}

The essential oils of Peumus boldus, Laurelia sempervirens, and Laureliopsis philippiana have insecticidal properties by contact toxicity as well as fumigant and repellent action against Sitophilus zeamais.

\section{LITERATURE CITED}

Abbott, W.S. 1925. A method of computing the effectiveness of an insecticide. Journal of Economic Entomology 18:265-267.

Adams, R.P. 2007. Identification of essential oil component by gas chromatography/mass spectrometry. 804 p. Academic Press, New York, USA.

Aslan, I., H. Ozbek, S. Kordali, O. Calmasur, and A. Cakir. 2004. Toxicity of essential oil vapours obtained from Pistacia spp. to the granary weevil, Sitophilus zeamais (L.) (Coleoptera: Curculionidae). Journal of Plant Diseases and Protection 111:400-407.

Betancur, J., G. Silva, J.C. Rodríguez, S. Fischer, and N. Zapata. 2010. Insecticidal activity of Peumus boldus Molina essential oil against Sitophilus zeamais Motschulsky. Chilean Journal of Agricultural Research 70:399-407.

Bittner, M., M.E., Casanueva, C. Arbert, M. Aguilera, V. Hernández, and J. Becerra. 2008. Effects of essential oils from five plants species against the granary weevil Sitophilus zeamais and Acanthoscelides obtectus (Coleoptera). Journal of Chilean Chemical Society 53:1455-1459. 
Coitinho, R.L., J.V. De Oliveira, M.G. Correa, e C.A. Gomes. 2011. Toxicidade por fumigação, contato e ingestão de óleos essenciais para Sitophilus zeamais Motschulsky, 1885 (Coleoptera: Curculionidae). Ciência e Agrotecnologia 35:172-178.

Conti, B., A. Canale, P.L. Cioni, and G. Flamini. 2010. Repellence of essential oil from tropical and mediterranean lamiaceae against Sitophilus zeamais. Bulletin of Insectology 63:197-202.

Huang, Y., H. Ho, H. Lee, and H. Yap. 2002. Insecticidal properties of eugenol, isoeugenol and methyleugenol and their effects on nutrition of Sitophilus zeamais Motsch. (Coleoptera: Curculionidae) and Tribolium castaneum. (Coleoptera: Tenebrionidae). Journal of Stored Product Research 38:403-412.

Isman, M. 2000. Plant essential oil for pest and disease management. Crop Protection 19:603-608.

Kouninki, H., T. Hance, F.A. Noudjou, G. Lognay, F. Malaisse, and M.B. Ngassoum. 2007. Toxicity of some terpenoids of essential oils of Xylopia aethiopica from Cameroon against Sitophilus zeamais Motschulsky. Journal Applied Entomology 131:269-274.

Lee, B.H., P.C. Annis, F. Tumaalii, and W. Choi. 2004. Fumigant toxicity of essential oil from the myrtaceae family and 1,8-cineole against 3 major stored-grain insects. Journal of Stored Products Research 40:553-564.

Montenegro, I., A. Madrid, L. Zaror, R. Martínez, E. Werner, H. Carrasco-Altamirano, et al. 2012. Antimicrobial activity of ethyl acetate extract and essential oil from bark of Laurelia sempervirens against multiresistant bacteria. Boletín Latinoamericano y del Caribe de Plantas Medicinales y Aromáticas 11:306-315.

Nerio, L.S., J. Olivero-Verbel, and E.E. Stashenko. 2009. Repellent activity of essential oil from seven aromatic plants grown in Colombia against Sitophilus zeamais Motschulsky (Coleoptera). Journal of Stored Products Research 45:212-214.

Niemeyer, H., y S. Teillier. 2007. Aromas de la flora nativa de Chile. 448 p. Universidad de Chile/Fundación para la Innovación Agraria, Santiago, Chile.

Obeng-Oferi, D., and C.H. Reichmuth. 1997. Bioactivity of eugenol, a major component of essential oil of Ocimum suave (Wild.) against four species of stored-product Coleoptera. International Journal of Pest Management 43:89-94.

Ortiz, U.A., G. Silva, A. Urbina, N. Zapata, J.C. Rodríguez, and A. Lagunes. 2012. Bioactivity of tepa (Laurelopsis philippiana (Looser) Shodde) powder to Sitophilus zeamais Motschulsky control in laboratory. Chilean Journal of Agricultural Research 72:68-73

Pérez, F., G. Silva, M. Tapia, y R. Hepp. 2007. Variación anual de las propiedades insecticidas de Peumus boldus sobre Sitophilus zeamais. Pesquisa Agropecuaria Brasileira 42:633-639.

Pimentel, M.A.G., L.R.D'A. Faroni, R.N.C. Guedes, A.H. Sousa, and M.R. Tótola. 2009. Phosphine resistance in Brazilian populations of Sitophilus zeamais Motschulsky (Coleoptera: Curculionidae). Journal of Stored Products Research 45:71-74.
Pires, J., J. De Morais, e S. De Bortoli. 2006. Toxicidade de óleos essenciais de Eucalyptus spp. sobre Callosobruchus maculatus (Fabr., 1775) (Coleoptera: Bruchidae). Revista de Biologia e Ciéncia da Terra 6:96-103.

Procopio, S., J. Vendramin, J. Ribeiro, e J. Santos. 2003. Bioatividade de diversos pós de origen vegetal em relaçao a Sitophilus zeamais Mots. (Coleoptera: Curculionidae). Ciencia e Agrotecnologia 27:1231-1236.

Restello, R.M., C. Menegatt, e A.J. Mossi. 2009. Efeito do oleo essencial de Tagetes patula L. (Asteraceae) sobre Sitophilus zeamais Motschulsky (Coleoptera, Curculionidae). Revista Brasileira de Entomologia 53:304-307.

Ribeiro, B.M., R.N.C. Guedes, E.E. Oliveira, and J.P. Santos. 2003. Insecticide resistance and synergism in Brazilian populations of Sitophilus zeamais (Coleoptera: Curculiondae). Journal of Stored Products Research 39:21-31.

Robertson, J.L., and H.K. Preisler. 1992. Pesticide bioassays with arthropods. 224 p. CRC Press, Boca Raton, Florida, USA.

Salgado, N., L.R.D. Faroni, y A. Soto. 2012. Aceite esencial de Piper crassinervum para el control de Sitophilus zeamais (Coleoptera: Curculionidae). Boletín Científico del Museo de Historia Natural 16:99-107.

Samboon, S., and S. Pimsamarn. 2006. Biological activity of Cleome spp. extracts against the rice weevil, Sitophilus oryzae $\mathrm{L}$. Agricultural Science Journal 37:232-235.

Shelly, T.E., and J. Edu. 2008. Do methyl eugenol-fed males of the oriental fruit fly (Diptera:Tephritidae) induce female re-mating. Florida Entomologist 91:388-393.

Tapondjou, A.L.C., D.A. Adler, H. Fontem, F. Bouda, and C. Reichmuth. 2005. Bioactivities of cymol and essential oils of Cupressus sempervirens and Eucalyptus saligna against Sitophilus zeamais Motschulsky and Tribolium confusum du Val. Journal of Stored Products Research 41:91-102.

Urzúa A., R. Santander, J. Echeverría, C. Villalobos, S.M Palacios, and Y. Rossi. 2010. Insecticidal properties of Peumus boldus Mol. essential oil on the house fly, Musca domestica L. Boletín Latinoamericano y del Caribe de Plantas Medicinales y Aromáticas 9:465-469.

Vargas, R.I., J.D. Stark, M.H. Kido, H.M. Ketter, and L.C. Whitehand 2000. Methyl eugenol and cue-lure traps for suppression of male oriental fruit flies and melon flies (Diptera:Tephritidae) in Hawaii: effects of lure mixtures and weathering. Journal of Economic Entomology 93:81-87.

Vogel, H., I. Razmilic, y U. Doll. 1997. Contenido de aceite esencial $\mathrm{y}$ alcaloides en diferentes poblaciones de boldo (Peumus boldus Mol.) Ciencia e Investigación Agraria 24:1-6.

Yano, K., and H. Kamimura. 1993. Antifeedant activity toward larvae of Pieris rapae crucivora of phenolethers related to methyleugenol isolated from Artemisia capillaris. Bioscience Biotechnology and Biochemistry 57:129-130. 